\title{
White-Collar Crime and Civil Sanctions
}

\author{
Abraham S. Goldstein $\dagger$
}

In his comprehensive review and assessment of "punitive civil sanctions," Professor Kenneth Mann has shown us that the prosecution of white-collar crime is being transformed. ${ }^{1}$ The criminal law is now being used not only to imprison offenders but also to provide the basis for financial remedies, such as forfeiture, profit-fines, and restitution. Probation is being used to impose conditions on businessmen and corporations, making it the functional counterpart of injunctive remedies. And civil damage actions are being brought to supplement criminal cases-sometimes for treble damages or for punitive damages. Either the state or the victims of the offenses, alone or in class actions, may bring these damage actions. There is even talk of allowing private parties once again to initiate certain kinds of criminal prosecutions, in addition to or in lieu of the state.

The conduct ordinarily described as white-collar crime ${ }^{2}$ is under attack in all the ways available to the regulatory state-through criminal, civil, and administrative law. The objective seems to be to achieve the state's regulatory purpose unimpeded by the "technical" limits imposed by criminal law or criminal procedure. This results in the erosion of formal distinctions between "criminal" and "civil" actions. The erosion, by collapsing traditional categories, has created a serious risk that the central role of criminal law in a system of sanctions may be compromised or even lost.

In this Comment, I would like to supplement Professor Mann's observations by describing some of the currents in criminal law, criminology, and public opinion that have brought us to our present situation.

The central concepts of what we now regard as a distinctive body of criminal law emerged from cases involving crimes of passion, violence, and

$\dagger$ Sterling Professor of Law, Yale Law School.

1. Kenneth Mann, Punitive Civil Sanctions: The Middleground Between Criminal and Civil Law, 101 YALE L.J. 1795 (1992).

2. When I refer to white-collar crime, I have in mind the crimes committed by individuals or organizations, usually in the course of business activity, and usually characterized by fraud or falsehood and by complexity. Such crimes occur in the fields of finance and industry where the context is typically one of a group or an organization, the dangers addressed are less tangible, the culpability of defendants is less plain, and the conduct is less obviously immoral. 
theft. These concepts take as their model the genuinely culpable individual who "deserves" to be used for the criminal law's purposes-whose condemnation will assuage retributive impulses, deter potential offenders, reinforce legal norms, and lead to incarceration of the demonstrably dangerous. Much of contemporary scholarly writing embraces this model and treats it as fundamental, as inherent in the very concept of crime. To lack culpability (blameworthiness), it is said, is not to be a criminal at all. The underlying assumptions are that criminal law is less concerned with social control of deviant behavior than with defining who should be used in that effort, and that criminal law is a technique of social control which is to be used sparingly - with a wholesome regard for its stigmatizing power and the extraordinary pains imposed by imprisonment.

This attitude underlies the very important United States Supreme Court opinion, Morissette v. United States. ${ }^{3}$ In that case, the Court held that mens rea was required for criminal liability even when the statute creating the crime does not use any of the talismanic words of mens rea, such as malice, intent, knowledge, or recklessness. In effect, the Court said that a legislature must virtually negate the mens rea requirement before it will construe a statute as having imposed strict liability. The Model Penal Code of the American Law Institute (ALI) has largely adopted this position: if the state wishes to punish conduct without a showing of some mens rea, it must call the conduct a violation, not a crime; it may not imprison the offender; and it may impose only de minimis sanctions. ${ }^{4}$

Those who embrace the dominant theory have treated as virtually illegitimate the older lines of cases that reflected an entirely different theory-one that focused more on achieving social control than on assessing personal culpability. This secondary theory is exemplified in the opinions of English and American courts dealing with offenses like bigamy and adultery-older versions of what we now tend to call public welfare offenses. ${ }^{5}$ Those opinions reflected a willingness on the part of courts and legislatures to abandon, or at least to limit sharply, a subjective theory of liability when necessary to achieve important social objectives. As Holmes pointed out in his famous essay The Criminal $L a w,{ }^{6}$ from the beginnings of our criminal law, courts have not hesitated to impose criminal liability on those who are only objectively liable. And that perspective has endured to the present day. Our Supreme Court has upheld the imposition of strict liability, or liability for negligence or vicarious liability, for offenses carrying very heavy prison sentences. ${ }^{7}$ Those cases, like the earlier

3. 342 U.S. 246 (1952).

4. See MODEL PENAL CODE $\S \S 1.04(5), 2.05(1)$ (a) (Proposed Official Draft 1962),

5. See WAYNE R. LAFAVE \& AUSTIN W. SCOTT, JR., CRMMINAL LAW $\$ 5.1(b)$ at 408-09 (2d ed. 1986).

6. OLIVER W. HOLMES, The Criminal Law, in THE COMMON LAW 39-76 (Boston, Little, Brown \& Co. 1881$)$.

7. See, e.g., United States v. Dotterweich, 320 U.S. 277 (1943); United States v. Balint, 258 U.S. 250 (1922). 
ones, assume that to achieve social control it may be necessary to abandon the mens rea requirement or to keep notions of subjective culpability to a minimum.

The two theories of criminal liability - one emphasizing social control and the other stressing personal culpability-have long been competing for primacy, most conspicuously in the law of traditional crimes. Doctrines based on objective theories of liability (like the felony murder rule or vicarious responsibility) have met fierce criticism. ${ }^{8}$ For the most part, the advocates of personal culpability and strict procedures have won the contest. But in doing so, they have tended to carry their critique beyond the traditional crimes to which it had been addressed - the crimes of passion and violence and theft. These crimes are indeed "personal" and are easy targets for a subjective theory. It is less clear that the subjectivist critique has equal application to the new types of crimes. These are usually characterized by vague definitions and by the abandonment or reduction of the mens rea requirement, as legislatures try to respond to the pressures of the Industrial Revolution and the regulatory state. Nevertheless, the academic community and the ALI have tended to describe the law on the books as if it had already accepted the subjective theory of liability across the board.

This apparent consensus has made legislatures, courts, and prosecutors reluctant to use criminal law to achieve the kind of social control that is the raison d'être of many of the new regulatory crimes. Thus, by narrowing the boundaries of the area that may or should be reached by criminal law, the reformers have created strong pressures on the courts either (1) to stretch criminal law beyond the newly proper ("subjectivist") boundaries, or (2) to avoid the constraints associated with criminal law and criminal procedure by abandoning the criminal law as a regulatory tool. The latter course, abandonment, would obviously be easier if civil measures were available that could do better, and more efficiently, the work of criminal law in the specialized areas associated with white-collar crime.

\section{II}

The increasing prominence of civil sanctions also receives support from Edwin Sutherland's influential theory of white-collar crime and from the populist impulses latent in that theory. ${ }^{9}$ In his studies of high status individuals who had violated the law, Sutherland counted as crimes events that "were rarely prosecuted in criminal court: they were violations of administrative rules or simply contract cases to be processed, if at all, in civil court. ${ }^{, 10}$ In his view,

8. For a summary of the various positions, see MODEL PENAL CODE AND COMMENTARIES $\$ 2.06 \mathrm{cmt}$ at 302 (1985); Id. \& $210.2 \mathrm{cmt}$ at 30 (1980); LAFAVE \& SCOTT, supra note 5, at $\$ \S 3.9(\mathrm{~d}), 7.5$.

9. EDWIN H. SUTHERLAND, WHITE COLLAR CRMME (1949).

10. See Stanton Wheeler, White-Collar Crime, in 4 ENCYCLOPEDIA OF CRME AND JUSTICE 1652, 1653 (Sanford Kadish ed., 1983) (discussing SUTHERLAND, supra note 9). 
it was overly technical to act as if crimes do not exist because they have not led to prosecution and conviction. He also believed that the criminal charge was an especially unreliable guide to the nature and extent of crime because whitecollar offenders were prosecuted less often and punished less severely than ordinary offenders were.

Sutherland's work on white-collar crime provides a direct link to a regulatory approach that locates criminal law alongside the other methods of controlling deviant behavior. A corollary of that approach is that policymakers in complex economic and technological areas must take into account that, for those persons whose conduct they are trying to reach, the fruits of offending outweigh the harm of punishment. From this perspective, the difficulty of effectuating public policy against such offenders makes it necessary to augment the criminal law with a wider range of sanctions and processes.

The connotation of the term "white-collar crime" has had a powerful effect on public attitudes and on the content of criminal law and criminal procedure. The term evokes a highly emotive image of great corporations and those who run them making all of us their victims-overcharging us for our purchases, polluting our environment, and making us less safe so that they may make more money. These are the consummately rational offenders who know what they are doing to us, who are motivated by greed, and who get away with their conniving. In dealing with such offenders, the argument continues, the criminal law is beset with technicalities that sacrifice regulatory objectives on the altar of a pure doctrine of personal culpability. That doctrine may have a place in conventional criminal law where a wide array of sociological and psychological "explanations" for crime exists and where defendants are seen as poor and untutored, often abused by the police, and needing protection from excessive interrogation and arbitrary searches. For such defendants, it may seem appropriate to indulge in doctrines favoring innocence. White-collar offenders, on the other hand, are widely perceived as deserving little or no sympathy because of their status, wealth, and education.

The spotlight that the social science literature and the popular media have focused on alleged favoritism for the affluent has contributed to a reduction in the protections accorded to defendants in cases of white-collar crime. Notions of personal guilt are readily abandoned as negligence, strict liability, and vicarious liability are routinely put to use. Concepts like "enterprise" and "pattern of racketeering activity" are permitted to take their places alongside "conspiracy" as even looser vehicles for imposing group and vicarious liability. "The maxim that criminal statutes must be construed strictly is often replaced with a principle of liberal construction in favor of the government. The

11. Racketeer Influenced and Corrupt Practices Act (RICO), 18 U.S.C. $\S \S 1961-1968$ (1988); $c f$. Abraham S. Goldstein, Conspiracy to Defraud the United States, 68 YALE L.J. 405, 463 (1959) (characterizing conspiracy under federal law as "a Kafkaesque crime, unknown and unknowable except in terms of the facts of each case--and even then, not until the verdict has been handed down"). 
law of presumptions is stretched to make up for expected difficulties of proof in complex cases. And the courts tolerate an extraordinary measure of vagueness in defining crime. Reducing these protections has provided an incentive to "decriminalize" white-collar offenses-by adding more easily applied and substitutable civil sanctions-not out of sympathy for these offenders but to be "tougher" on them and to regulate their conduct more effectively.

\section{III}

What we now have is a helter-skelter cumulation of processes and sanctions. Civil processes and sanctions have emerged that are often more punitive than criminal processes but equally stigmatizing. ${ }^{12}$ Yet civil sanctions may bring with them fewer procedural protections than do criminal sanctions: they may be established by a preponderance of evidence, and need not meet the proof beyond a reasonable doubt standard; they may be instituted by private parties without being screened by a public prosecutor serving as surrogate for the public interest; and they may be tried by a judge rather than a jury.

Professor Mann has demonstrated that we are at a critical divide. We who teach and write on criminal law have been so absorbed with traditional crimes that we have slighted a new field that competes directly with the criminal law and threatens to supplant it. The challenge now is to separate out the several strands-to recognize that each civil and criminal remedy is part of a network of sanctions designed to control deviant behavior; to provide screening mechanisms to determine which sanction should be brought to bear, and by whom, in order to make law enforcement more effective overall; and to create the hybrid procedures uniquely appropriate to each of these hybrid processes. If we do not succeed in meeting this challenge, there is a genuine risk that the stigma and sanctions associated with "crime" will be imposed, in both civil and criminal processes, on persons who are not culpable in any widely accepted sense of that term. If that happens, if offenders who do not match the public image of criminality are too casually found to be criminal, the "crime" label will lose its incremental utility, the moral force of the criminal sanction will be dissipated, and many more people will suffer unjust treatment.

12. For example, civil sanctions include deprivation of a license, barring a person from holding office, deportation, civil commitment, and forfeiture. 
. 